\title{
Characterization of Lactobacilli by Southern-Type Hybridization with a Lactobacillus plantarum pyrDFE Probe
}

\author{
FRANÇOISE BRINGEL, ${ }^{*}$ MARIE-CHRISTINE CURK, AND JEAN-CLAUDE HUBERT \\ Laboratoire de Microbiologie et de Génétique URA Centre National de la Recherche \\ Scientifique D 1481, Institut de Botanique, 67083 Strasbourg, France
}

\begin{abstract}
Lactobacillus plantarum, Lactobacillus pentosus, and Lactobacillus paraplantarum (M.-C. Curk, J.-C. Hubert, and F. Bringel, Int. J. Syst. Bacteriol. 46:595-598, 1996) can hardly be distinguished on the basis of their phenotypes. Unlike $L$. plantarum and $L$. paraplantarum, $L$. pentosus ferments glycerol and xylose but not melezitose. We identified two L. pentosus strains (CNRZ 1538 and CNRZ 1544) which ferment glycerol and melezitose but not xylose. $\alpha$-Methyl-D-mannoside was fermented by $66 \%$ of the $L$. plantarum strains tested but not by $L$. paraplantarum strains. In this paper we describe a simple method to identify $L$. plantarum, $L$. pentosus, and $L$. paraplantarum. This method is based on nonradioactive Southern-type hybridization between BglI DNA digests of the lactobacilli tested and a DNA probe ( $L$. plantarum pyrDFE genes from strain CCM 1904). A total of 68 lactobacilli were classified into five groups on the basis of the bands detected. Two groups contained $L$. plantarum strains; one of these groups contained 31 strains, including the type strain, and was characterized by bands at 7, 4, and $1 \mathrm{~kb}$, and the other group contained strain LP 85-2 and was characterized by bands at 5 and $1.1 \mathrm{~kb}$. Only one band (a band at around $7 \mathrm{~kb}$ ) was detected in the strains belonging to the $L$. pentosus group, and two bands (at 4 and $1 \mathrm{~kb}$ ) were found in the strains belonging to the L. paraplantarum group. No hybridization was detected in the last group, which contained Lactobacillus casei, Lactobacillus coryniformis, Lactobacillus paracasei, Lactobacillus brevis, Lactobacillus delbrueckii, and Lactobacillus leichmannii strains.
\end{abstract}

Lactobacilli related to Lactobacillus plantarum are lactic acid bacteria that are important in many plant fermentations (silage, pickled vegetables, sourdough) and meat and fish fermentations (17). Some of these organisms, such as the organisms found in beer, also can be food spoilage agents (19), and some lactobacilli are also found in cavities of mammals (16).

The taxonomy of $L$. plantarum is not satisfactory (13); this species contains strains that have similar biochemical characteristics but exhibit little similarity at the DNA level. Dellaglio et al. (9) identified the following three groups on the basis of DNA-DNA hybridization data: $L$. plantarum, Lactobacillus pentosus, and an atypical $L$. plantarum group recently reclassified as Lactobacillus paraplantarum (7). In agreement with the results of Dellaglio et al. (9), Zanoni et al. (24) revived the name $L$. pentosus for a distinct taxon; $L$. pentosus can be distinguished from $L$. plantarum by its ability to produce acid from D-xylose and glycerol $(10,13)$. However, these phenotypic characteristics are not sufficient to distinguish $L$. plantarum from L. pentosus since some strains ferment glycerol but not D-xylose (this study) or D-xylose but not glycerol (16). Direct sequencing of $16 \mathrm{~S}$ rRNAs by reverse transcription clarified the phylogenetic status of several groups of lactic acid bacteria but could not be used to distinguish $L$. plantarum from $L$. pentosus since the $16 \mathrm{~S}$ rRNA sequences of these organisms displayed a very high level of homology (ca. 99\%) (6). Fourier transform infrared spectroscopy can be used to identify lactobacilli found in breweries, but $L$. pentosus could not be distinguished from $L$. plantarum by Curk et al. (8) on the basis of the spectra which they studied.

Until now, the only reliable method to discriminate between strains related to L. plantarum has been the liquid DNA-DNA hybridization technique $(9,24)$. Unfortunately, this method is time consuming and cannot be used routinely. A simple meth-

* Corresponding author. Mailing address: Laboratoire de Microbiologie et de Génétique URA CNRS D 1481, Institut de Botanique, 28 rue Goethe, 67083 Strasbourg, France. Phone: (33) 88-24-41-53. Fax: (33) 88-35-84-84. Electronic mail address: bringel@gem.u-strasbg.fr. od is necessary. In this paper, we describe a method based on Southern-type hybridization (20). The DNAs of the lactobacilli examined were restricted with $B g l \mathrm{I}$ and probed with $L$. plantarum genes of the pyrimidine de novo pathway. Genes of the de novo UMP biosynthetic pathway are conserved in live cells. Six enzymatic steps are required for the biosynthesis of UMP from glutamine, bicarbonate, and ATP. The last three enzymes are dihydroorotate dehydrogenase, orotidine monophosphate (OMP) pyrophosphorylase, and OMP decarboxylase, which are encoded by pyrD, pyrE, and $p y r F$, respectively. These activities were present in $140 \mathrm{~L}$. plantarum-related strains studied for their pyrimidine requirements in the laboratory (unpublished data). The three genes were cloned and sequenced and were shown to be contiguous on the chromosome of $L$. plantarum CCM 1904 (= ATCC 8014) $(1,2)$. For these reasons, we decided to test whether the L. plantarum CCM 1904 pyrDFE genes could be used as a taxonomic tool for distinguishing strains related to L. plantarum.

\section{MATERIALS AND METHODS}

Strains and growth conditions. The sources of the strains which we used are shown in Table 1 . Most strains were propagated in MRS broth (Difco) at $30^{\circ} \mathrm{C}$; the exceptions were strains ATCC 8008B, ATCC 8008G, ATCC 10776, and ATCC 13649 , which were incubated at $37^{\circ} \mathrm{C}$. Glycine was added at a concentration of $2.5 \%$ when cells were lysed for DNA extraction.

Carbohydrate fermentative profites. Fermentation of 49 carbohydrates was studied by using API $50 \mathrm{CH}$ strips with API $50 \mathrm{CHL}$ medium (bioMérieux)

DNA preparation. The genomic DNAs used for the Southern-type hybridization experiments and DNA-DNA liquid hybridization experiments were extracted as described by Vanderslice et al. (22) and Champomier et al. (3), respectively.

Southern-type hybridization. The probe used in the Southern-type hybridization experiments consisted of the pyrDFE genes $(1,2)$ of $L$. plantarum CCM 1904. The genomic DNA was released from bacterial cells by heating a preparation in sterile bidistilled water (approximately $10^{5}$ cells in $40 \mu \mathrm{l}$ of water) at $94^{\circ} \mathrm{C}$ for $10 \mathrm{~min}$. The lysate was put on ice, and the cell debris was removed by centrifugation. A 4- $\mu$ l portion of the supernatant was used as a template in a PCR performed with Taq DNA polymerase (Eurogentec) and the following primers: primer LP-D (5'-CATATGGTCAACAGATGGCTCAACAG-3') and primer LP-R (5'-TGACGCCACGTATGCAGCGAAGC-3'). Primer LP-D includes the start codon of pyrD, and primer LP-R is located 31 nucleotides from 
TABLE 1. Lactobacillus strains

\begin{tabular}{|c|c|c|c|}
\hline Name as received & $\begin{array}{l}\text { Name determined } \\
\text { in this study }\end{array}$ & Strain $^{a}$ & Source \\
\hline L. brevis & & CNRZ 425 & Isolated from bread dough in France \\
\hline L. brevis & & CNRZ 738B & Isolated from silage \\
\hline L. brevis & & CST 10550 & \\
\hline L. brevis & & CST 10932 & Isolated from beer wort in France \\
\hline L. brevis & & DSM $20054^{T}$ & \\
\hline L. brevis & & IOI-O8-75 & Obtained from the Centre de Formation API, La Balme-les-Grottes, France \\
\hline L. casei & & $64 \mathrm{HG}$ & Obtained from F. Gasser, Institut Pasteur, Paris, France \\
\hline L. coryniformis subsp. coryniformis & & DSM $20001^{\mathrm{T}}$ & \\
\hline L. delbrueckii subsp. lactis & & DSM 20076 & \\
\hline L. leichmannii & & NCIMB 8964 & \\
\hline L. paracasei & & CST 10927 & Isolated from brewery syrup \\
\hline L. paracasei subsp. paracasei & & CIP 53.166 & \\
\hline L. paracasei & & DSM 20020 & Isolated from saliva \\
\hline L. plantarum & L. paracasei & NCIMB 3254 & Isolated from cheese \\
\hline L. plantarum & L. pentosus & CNRZ 1537 & Isolated from fermented olives in Spain \\
\hline L. plantarum & L. pentosus & CNRZ 1538 & Isolated from fermented olives in Spain \\
\hline L. plantarum & L. pentosus & CNRZ 1544 & Isolated from fermented olives in Spain \\
\hline L. plantarum & L. pentosus & CNRZ 1546 & Isolated from fermented olives in Spain \\
\hline L. plantarum & L. pentosus & CNRZ 1547 & Isolated from fermented green olives in Spain \\
\hline L. plantarum & L.pentosus & CNRZ 1552 & Isolated from fermented olives in Spain \\
\hline L. plantarum & L.pentosus & CNRZ 1555 & Isolated from fermented olives in Spain \\
\hline L. plantarum & L.pentosus & CNRZ 1558 & Isolated from fermented green olives in Spain \\
\hline L. plantarum & L. pentosus & CNRZ 1561 & Isolated from fermented green olives in Spain \\
\hline L. plantarum & L.pentosus & CNRZ 1569 & Isolated from fermented olives in Spain \\
\hline L. plantarum & L. pentosus & CNRZ 1570 & Isolated from fermented olives in Spain \\
\hline L. plantarum & L.pentosus & CNRZ 1573 & Isolated from fermented green olives in Spain \\
\hline L. plantarum & L. pentosus & Hansen & Laboratory strain \\
\hline L. pentosus & & NCFB $363^{\mathrm{T}}$ & \\
\hline L. pentosus & & NCIMB 8531 & Isolated from waste sulfite liquor \\
\hline L. plantarum & L. paraplantarum & $61 \mathrm{D}$ & $\begin{array}{l}\text { Isolated from human feces; obtained from F. Gasser, Institut Pasteur, Paris, } \\
\text { France; equivalent to CIP } 104445\end{array}$ \\
\hline L. plantarum & & Agrano $15 b$ & Laboratory strain isolated from bread dough \\
\hline L. plantarum & L. paraplantarum & ATCC $10776^{b}$ & \\
\hline L. plantarum & & ATCC $13649^{b}$ & Isolated from cheddar cheese; formerly called $L$. plantarum var. rudensis \\
\hline L. plantanum & & ATCC $14917^{\mathrm{T}}$ & Isolated from pickled cabbage \\
\hline L. plantarum & & CCM 1904 & Isolated from corn silage; equivalent to ATCC 8014 \\
\hline L. plantarum & & CIP 71.39 & \\
\hline L. plantarum & & CNRZ 184 & \\
\hline L. plantarum & & CNRZ 424 & Isolated from bread dough in France \\
\hline L. plantarum & & CNRZ 738 & Isolated from silage in France \\
\hline L. plantarum & & CNRZ 764 & Isolated from cheese in France \\
\hline L. plantarum & & CNRZ 1228 & Isolated from Domiati cheese in Egypt \\
\hline L. plantarum & & CNRZ 1246 & Isolated from Domiati cheese in Egypt \\
\hline L. plantarum & & CST 10928 & Isolated from recycled beer bottles \\
\hline L. plantarum & & CST 10952 & \\
\hline L. plantarum & L. paraplantarum & CNRZ 1887 & Isolated from beer \\
\hline L. plantarum & L. paraplantarum & CNRZ $1885^{\mathrm{T}}$ & Isolated from beer; equivalent to CIP 104668 \\
\hline L. plantarum & & CST 10967 & Isolated from beer \\
\hline L. plantarum & & CST 11019 & Isolated from beer \\
\hline L. plantarum & & CST 11023 & Isolated from beer \\
\hline L. plantarum & & CST 11031 & Isolated from beer \\
\hline L. plantanum & & CST 12009 & Isolated from dairy products \\
\hline L. paracasei & L. plantarum & DSM 2648 & Isolated from silage \\
\hline L. plantarum & & $\mathrm{Hd} 4$ & Obtained from A. Mourey, Nancy University, Villers-les-Nancy, France \\
\hline L. plantarum & & Hd17 & Obtained from A. Mourey, Nancy University, Villers-les-Nancy, France \\
\hline L. plantarum & & LP $85-2$ & $\begin{array}{l}\text { Isolated from grass silage; obtained from E. Armau, CNRS, University Paul- } \\
\text { Sabatier, Toulouse, France }\end{array}$ \\
\hline
\end{tabular}

the end of pyrE. The PCR consisted of denaturation at $94^{\circ} \mathrm{C}$ for $30 \mathrm{~s}$, hybridization at $61^{\circ} \mathrm{C}$ for $30 \mathrm{~s}$, and elongation at $72^{\circ} \mathrm{C}$ for $2 \mathrm{~min}$; this cycle was repeated 40 times. A $2.2-\mathrm{kb}$ fragment was obtained and subsequently labelled with a nonradioactive DIG DNA labelling and detection kit (Boehringer Mannheim). This probe could be stored for more than 1 year at $-20^{\circ} \mathrm{C}$. (In addition to PCR isolation, the $2.2-\mathrm{kb}$ fragment can also be isolated from plasmid pF5 [1] digested with restriction enzymes $N d e \mathrm{I}$ and $B s t \mathrm{XI}$.)

Lactobacillus genomic DNA was digested with restriction enzyme BglI (Gibco
BRL) before it was electrophoresed in a $0.7 \%$ agarose gel. We used digoxigeninlabelled lambda DNA cleaved with HindIII (Boehringer Mannheim) as a DNA molecular weight marker. The DNA was treated with $0.25 \mathrm{M} \mathrm{HCl}$ and transferred to a nylon membrane (Hybond- $\mathrm{N}^{+}$; Amersham) by the capillary action of a $0.4 \mathrm{M} \mathrm{NaOH}$ solution.

We used hybridization conditions which allowed hybridization of DNAs that exhibited a level of similarity of at least $65 \%$. Hybridization was performed at $50^{\circ} \mathrm{C}$ in the hybridization solution recommended by Boehringer Mannheim $(5 \times$ 
TABLE 1-Continued

\begin{tabular}{|c|c|c|c|}
\hline Name as received & $\begin{array}{l}\text { Name determined } \\
\text { in this study }\end{array}$ & Strain $^{a}$ & Source \\
\hline L. plantarum & & NCFB 772 & Isolated from cheese \\
\hline L. plantarum & & NCFB 963 & Isolated from cheese \\
\hline L. plantarum & & NCFB 965 & Isolated from cheese \\
\hline L. plantarum & & NCFB 1042 & Isolated from cheese \\
\hline L. plantarum & & NCFB 1204 & Isolated from cheese \\
\hline L. plantarum & & NCFB 2171 & Isolated from cheese \\
\hline L. plantarum & & NCIMB 1406 & Isolated from dental caries \\
\hline L. plantarum & & NCIMB 6461 & \\
\hline L. plantarum & & NCIMB 7220 & Isolated from pickled cabbage \\
\hline L. plantanum & & NCIMB 8299 & Isolated from silage \\
\hline Lactobacillus sp. & & ATCC $8008 \mathrm{G}^{c}$ & Isolated from butter \\
\hline Lactobacillus sp. & & ATCC $8008 \mathrm{~B}^{c}$ & Isolated from butter \\
\hline Lactobacillus sp. & & CST 10966J & \\
\hline
\end{tabular}

${ }^{a}$ ATCC, American Type Culture Collection, Rockville, Md.; CCM, Czechoslovak Collection of Microorganisms, Brno, Czech Republic; CNRZ, Centre National de Recherches Zootechniques, Jouy-en-Josas, France; CST, Collection Souches Tepral des brasseries Kronenbourg, Strasbourg, France; DSM, Deutsche Sammlung von Mikroorganismen und Zellkulturen GmbH, Braunschweig, Germany; NCFB, National Collection of Food Bacteria, Reading, United Kingdom; NCIMB, National Collection of Industrial and Marine Bacteria, Aberdeen, Scotland.

${ }^{b}$ These strains are not included in the current American Type Culture Collection catalog.

"Two lactobacilli were found in the strain ATCC 8008 tube sent by the American Type Culture Collection. ATCC 8008B and ATCC 8008G produced white dome-shaped and flat grey colonies, respectively. The sugar fermentation profiles of these organisms are given in Table 2.

SSC, $0.1 \%$ sarcosine, $0.01 \%$ sodium dodecyl sulfate [SDS], $1 \%$ blocking agent $[1 \times \mathrm{SSC}$ is $0.15 \mathrm{M} \mathrm{NaCl}$ plus $0.015 \mathrm{M}$ sodium citrate]). After hybridization, the membrane was washed with wash solution $(2 \times \mathrm{SSC}, 0.1 \%$ SDS $)$ twice at room temperature for $5 \mathrm{~min}$ and then twice at $50^{\circ} \mathrm{C}$ for $15 \mathrm{~min}$. The hybridized DNA was detected as recommended by Boehringer Mannheim.

DNA-DNA liquid hybridization. DNA was labelled by nick translation with $\left[{ }^{3} \mathrm{H}\right] \mathrm{dCTP}\left(30 \mathrm{Ci} \cdot \mathrm{mmol}^{-1} ;\right.$ Amersham $)$, dialyzed, and treated with $\mathrm{S} 1$ nuclease (12). DNA-DNA hybridization experiments were performed at $70^{\circ} \mathrm{C}$ after treatment with S1 nuclease and precipitation with trichloroacetic acid (12).

Thermal stability of DNA duplexes. After hybridization at $70^{\circ} \mathrm{C}$, the temperature was raised in $5^{\circ} \mathrm{C}$ increments. Each time that the temperature was raised, a sample of reassociated DNA $(100 \mu \mathrm{l})$ was treated with $\mathrm{S} 1$ nuclease $(15 \mu \mathrm{l})$ and then treated as described above for the DNA-DNA liquid hybridization procedure (12). We then extrapolated the temperature at which $50 \%$ of the doublestranded DNA was denatured $\left(T_{m}\right)$. The $\Delta T_{m}$ was the difference between the $T_{n}$ of the homologous duplex and the $T_{m}$ of the heterologous duplex.

\section{RESULTS}

Phenotypic characterization. A total of 53 lactobacilli were tested for the ability to ferment 49 carbohydrates, including glycerol and D-xylose, which are typically fermented by $L$. pentosus but not by L. plantarum (24); 15 of these lactobacilli fermented glycerol. A total of 13 of the 15 glycerol-fermenting strains also fermented D-xylose, suggesting that they were L. pentosus strains. Two strains, strains CNRZ 1538 and CNRZ 1544, did not ferment D-xylose, which raised the possibility that they were either $L$. pentosus or $L$. plantarum strains. As melezitose was catabolized by $81 \%$ of the L. plantarum strains tested (Table 2) and by none of the 13 strains

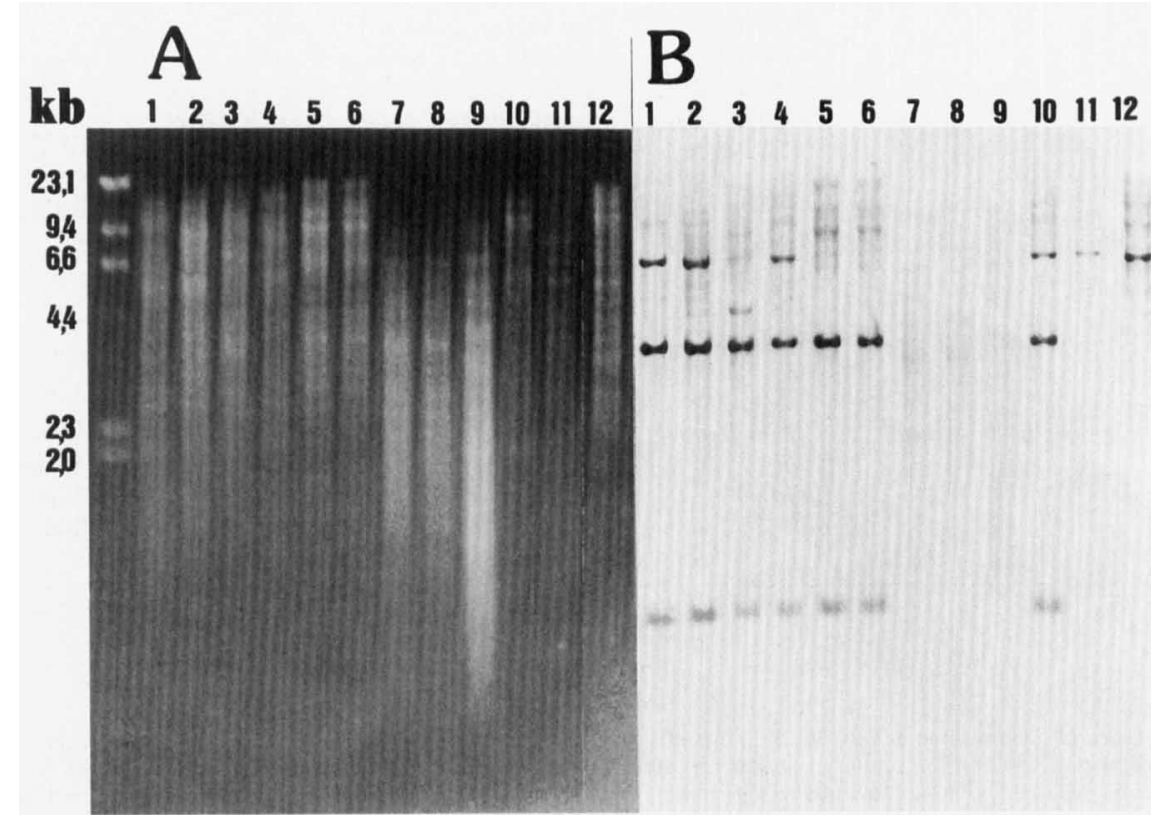

FIG. 1. Discrimination of Lactobacillus strains by Southern-type hybridization with an L. plantanum probe. (A) Agarose gel electrophoresis of BglI-restricted Lactobacillus genomic DNAs. (B) Hybridization of the Lactobacillus DNAs with the digoxigenin-labelled pyrDFE probe. Tracks 1, CCM 1904; tracks 2, CST 11019; tracks 3, ATCC 10776; tracks 4, ATCC 13649; tracks 5, CNRZ 1885' ${ }^{\mathrm{T}}$ t tracks 6, CNRZ 1887; tracks 7, ATCC 8008G; tracks 8, ATCC 8008B; tracks 9, NCIMB 8964; tracks 10, CNRZ 764; tracks 11, CNRZ 1569; tracks 12, CNRZ 1537. The DNA molecular size marker used was lambda DNA digested with HindIII. 
TABLE 2. Lactobacillus carbohydrate utilization profiles as determined with the API 50CHL system

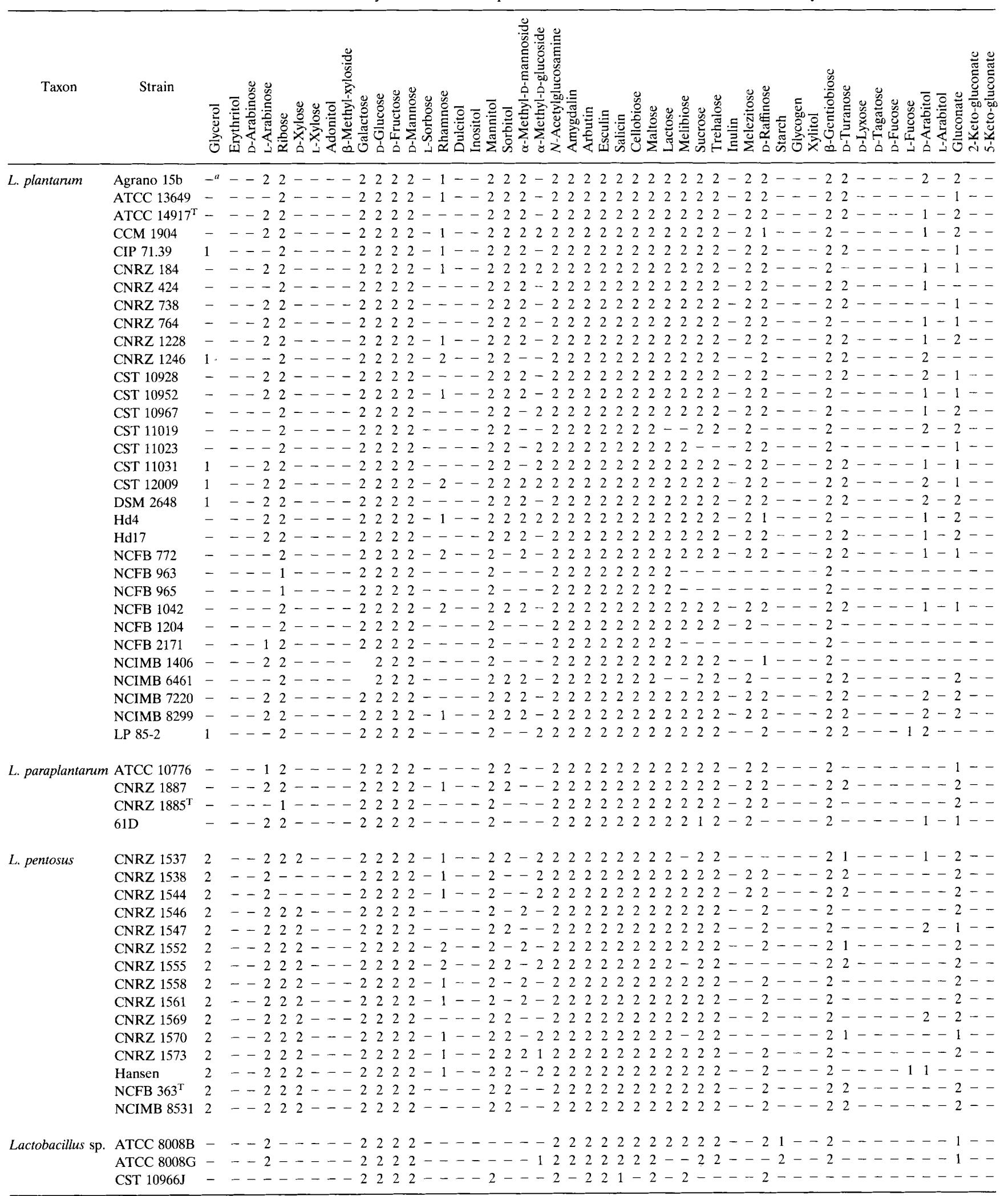

${ }^{a}-$, negative reaction; 2 , positive reaction; 1 , weak positive reaction. 
which fermented D-xylose, melezitose fermentation may also help distinguish L. plantarum from L. pentosus. Strains CNRZ 1538 and CNRZ 1544 produced acid from melezitose. We also found that ribose was fermented by all of the L. plantarum and L. pentosus strains tested except CNRZ 1538 and CNRZ 1544. Metabolism of sugars (raffinose and melibiose) has been shown to be temperature sensitive in L. plantarum CCM 1904 (21). In strains CNRZ 1538 and CNRZ 1544, different temperatures were used for ribose and D-xylose catabolism, but no fermentation was observed at 25,30 , or $37^{\circ} \mathrm{C}$. We concluded that CNRZ 1538 and CNRZ 1544 have atypical biochemical properties and cannot be assigned on the basis of phenotypic characteristics to either $L$. plantarum or $L$. pentosus.

$L$. paraplantarum (four strains) and $L$. plantarum ATCC $14917^{\mathrm{T}}(\mathrm{T}=$ type strain) could not be distinguished on the basis of biochemical and physiological characteristics (7). When we tested carbohydrate utilization with a larger number of L. plantarum strains (32 strains), we observed that $\alpha$-methylD-mannoside was catabolized by $66 \%$ of the $L$. plantarum strains but by none of the four L. paraplantarum strains (Table 2).

Southern-type hybridization with the $L$. plantarum pyrDFE probe. Previous workers have shown that strains classified as L. plantarum on the basis of their phenotypes have limited similarity at the DNA level $(9,24)$, so we assessed two stringencies of hybridization by changing the temperature of hybridization (see Materials and Methods). First, we tested highstringency conditions at $68^{\circ} \mathrm{C}$, but the $L$. plantarum probe did not hybridize with the L. pentosus strains (data not shown). When the temperature was lowered from 68 to $50^{\circ} \mathrm{C}$, hybridization with $L$. pentosus was detected (Fig. 1, lanes 11 and 12). This corresponded to the theoretical detection of DNA sequences that exhibit at least $65 \%$ similarity with the probe (calculated as suggested by the protocol of Boehringer Mannheim). The L. plantarum CCM 1904 pyrDFE genes have been sequenced, and two $B g l \mathrm{I}$ sites are separated by approximately $1 \mathrm{~kb}(2)$. In the Southern-type hybridization experiment performed with the entire 2.2-kb pyrDFE fragment, we expected three bands, including the $1-\mathrm{kb}$ fragment. When the CCM 1904 genome was digested with $B g l \mathrm{I}$ and hybridized, 7-, 4-, and 1-kb bands were detected, as shown in Fig. 1 (lane 1).

We tested 63 lactobacilli with the $L$. plantarum pyrDFE probe, and five groups were identified on the basis of the responses obtained (Table 3). Group 1 was characterized by bands at 7, 4, and $1 \mathrm{~kb}$ (Fig. 1, lanes 1, 2, 4, and 10) and contained 31 strains, including $L$. plantarum type strain ATCC 14917. Group 2 was characterized by bands at 5 and $1.1 \mathrm{~kb}$ and contained strain LP 85-2. Group 3 was characterized by bands at 4 and $1 \mathrm{~kb}$ (Fig. 1, lanes 3, 5, and 6) and contained the $L$. paraplantarum strains 61D, CNRZ 1887, ATCC 10776, and CNRZ $1885^{\mathrm{T}}(7)$. Group 4 was characterized by a band at around $7 \mathrm{~kb}$ (Fig. 1, lanes 11 and 12), which was detected in 15 strains, including $L$. pentosus type strain NCFB 363. Group 5 contained the strains which did not interact with the probe and included strains that are not related to $L$. plantarum, such as Lactobacillus brevis CNRZ 425, CST 10550, CST 10932, DSM $20054^{\mathrm{T}}$, and IOI-08-75, Lactobacillus casei $64 \mathrm{HG}$, Lactobacillus coryniformis DSM 20001 ${ }^{\mathrm{T}}$, Lactobacillus delbrueckii DSM 20076, Lactobacillus leichmannii NCIMB 8964 (Fig. 1, lane 7), Lactobacillus paracasei CIP 53.166, CST 10927, DSM 20020, and NCIMB 3254, and lactobacilli of undefined species (strains CST 10966J, ATCC 8008B, and ATCC 8008G) (Fig. 1, lanes 8 and 9).

Liquid DNA-DNA hybridization. To test whether the groups based on restriction fragment length polymorphisms of the pyr genes had taxonomic significance, liquid DNA-DNA hybrid-
TABLE 3. Southern-type hybridization performed with the L. plantarum pyrDFE probe and BglI-digested Lactobacillus genomic DNAs

\begin{tabular}{|c|c|c|}
\hline Group & Strain & $\begin{array}{l}\text { Size (s) of the band(s) } \\
\text { detected }(k b)\end{array}$ \\
\hline 1 & $\begin{array}{l}\text { L. plantarum Agrano } 15 \mathrm{~b} \\
\text { L. plantarum ATCC } 14917^{\mathrm{T}} \\
\text { L. plantarum ATCC } 13649 \\
\text { L. plantarum CCM } 1904 \\
\text { L. plantarum CIP } 71.39 \\
\text { L. plantarum CNRZ } 1228 \\
\text { L. plantarum CNRZ } 1246 \\
\text { L. plantarum CNRZ } 184 \\
\text { L. plantarum CNRZ } 424 \\
\text { L. plantarum CNRZ } 738 \\
\text { L. plantarum CNRZ } 764 \\
\text { L. plantarum CST } 10928 \\
\text { L. plantarum CST } 10952 \\
\text { L. plantarum CST } 10967 \\
\text { L. plantarum CST } 11023 \\
\text { L. plantarum CST } 11031 \\
\text { L. plantarum CST } 11019 \\
\text { L. plantarum CST } 12009 \\
\text { L. plantarum DSM } 2648 \\
\text { L. plantarum Hd4 } \\
\text { L. plantarum Hd17 } \\
\text { L. plantarum NCFB } 772 \\
\text { L. plantarum NCFB } 963 \\
\text { L. plantarum NCFB } 965 \\
\text { L. plantarum NCFB } 1042 \\
\text { L. plantarum NCFB } 1204 \\
\text { L. plantarum NCFB } 2171 \\
\text { L. plantarum NCIMB } 1406 \\
\text { L. plantarum NCIMB } 6461 \\
\text { L. plantarum NCIMB } 7220 \\
\text { L. plantarum NCIMB } 8299\end{array}$ & $\begin{array}{l}7.1,4,1 \\
7.1,4,1 \\
7.1,4,1 \\
7.1,4,1 \\
7.1,4,1 \\
7.1,4,1 \\
7.1,4,1 \\
7.1,4,1 \\
7.1,4,1 \\
7.1,4,1 \\
7.1,4,1 \\
7.1,4,1 \\
7.1,4,1 \\
7.1,4,1 \\
7.1,4,1 \\
7.1,4,1 \\
7.1,4,1 \\
7.1,4,1 \\
7.1,4,1 \\
7.1,4,1 \\
7.1,4,1 \\
7.1,4,1 \\
7.1,4,1 \\
7.1,4,1 \\
7.1,4,1 \\
7.1,4,1 \\
7.1,4,1 \\
7.1,4,1 \\
7.1,4,1 \\
7.1,4,1 \\
7.1,4,1\end{array}$ \\
\hline 2 & L. plantarum LP 85-2 & $5,1.1$ \\
\hline 3 & $\begin{array}{l}\text { L. paraplantanum 61D } \\
\text { L. paraplantarum ATCC } 10776 \\
\text { L. paraplantarum CNRZ } 1887 \\
\text { L. paraplantarum CNRZ } 1885^{\mathrm{T}}\end{array}$ & $\begin{array}{l}4,1 \\
4,1 \\
4,1 \\
4,1\end{array}$ \\
\hline 4 & $\begin{array}{l}\text { L. pentosus CNRZ } 1537 \\
\text { L. pentosus CNRZ } 1538 \\
\text { L. pentosus CNRZ } 1544 \\
\text { L. pentosus CNRZ } 1546 \\
\text { L. pentosus CNRZ } 1547 \\
\text { L. pentosus CNRZ } 1552 \\
\text { L. pentosus CNRZ } 1555 \\
\text { L. pentosus CNRZ } 1558 \\
\text { L. pentosus CNRZ } 1561 \\
\text { L. pentosus CNRZ } 1569 \\
\text { L. pentosus CNRZ } 1570 \\
\text { L. pentosus CNRZ } 1573 \\
\text { L. pentosus Hansen } \\
\text { L. pentosus NCFB } 363^{\mathrm{T}} \\
\text { L. pentosus NCIMB } 8531\end{array}$ & $\begin{array}{l}7.1 \\
7.5 \\
7.5 \\
7.5 \\
7.1 \\
7.5 \\
7.5 \\
7.5 \\
7.5 \\
7.1 \\
7.1 \\
7.5 \\
7.5 \\
7.5 \\
7.5\end{array}$ \\
\hline
\end{tabular}

ization was performed with the DNA of at least one member of each group and radiolabelled DNAs of type strains.

Under our experimental conditions, when $L$. pentosus NCFB $363^{\mathrm{T}}$ DNA was radiolabelled and probed with DNAs of lactobacilli belonging to the five groups, only the group 4 strains hybridized efficiently (levels of relative binding, $>82 \%$ ) (Table 4), confirming that these strains were $L$. pentosus strains.

When the radioactive DNA was from the L. plantarum type strain (ATCC 14917), high levels of relative binding were ob- 
TABLE 4. Levels of relative binding between L. pentosus NCFB $363^{\mathrm{T}}$ and L. plantarum ATCC $14917^{\mathrm{T}}\left[{ }^{3} \mathrm{H}\right] \mathrm{DNAs}$ and DNAs of other strains and thermal stabilities of some heteroduplexes

\begin{tabular}{|c|c|c|c|c|c|c|}
\hline \multirow{2}{*}{$\begin{array}{l}\text { Group based on } \\
\text { Southern data }\end{array}$} & \multirow{2}{*}{ Strain } & \multicolumn{2}{|c|}{ L. pentosus NCFB $363^{\mathrm{T}}$} & \multicolumn{2}{|c|}{ L. plantanum ATCC $14917^{\mathrm{T}}$} & \multirow{2}{*}{$\begin{array}{l}\text { Taxon based on liquid DNA- } \\
\text { DNA hybridization data }\end{array}$} \\
\hline & & $\%$ Hybridization & $\Delta T_{m}\left({ }^{\circ} \mathrm{C}\right)$ & $\%$ Hybridization & $\Delta T_{m}\left({ }^{\circ} \mathrm{C}\right)$ & \\
\hline \multirow[t]{10}{*}{4} & NCFB $363^{T}$ & & 0 & 50 & 8 & L. pentosus \\
\hline & CNRZ 1537 & 83 & & 32 & & L. pentosus \\
\hline & CNRZ 1544 & 95 & & 35 & & L. pentosus \\
\hline & CNRZ 1547 & 82 & 1.8 & 15 & & L. pentosus \\
\hline & CNRZ 1552 & 97 & & 25 & & L. pentosus \\
\hline & CNRZ 1555 & 93 & & 32 & & L. pentosus \\
\hline & CNRZ 1569 & 90 & & 50 & & L. pentosus \\
\hline & CNRZ 1570 & 91 & & 32 & & L. pentosus \\
\hline & CNRZ 1573 & 86 & & 25 & & L. pentosus \\
\hline & NCIMB 8531 & 95 & & 29 & & L. pentosus \\
\hline \multirow[t]{10}{*}{1} & ATCC $14917^{\mathrm{T}}$ & 20 & & 100 & 0 & L. plantarum \\
\hline & ATCC 13649 & 13 & & 98 & & L. plantarum \\
\hline & CCM 1904 & $\mathrm{ND}^{a}$ & & 90 & & L. plantarum \\
\hline & CIP 71.39 & ND & & 95 & & L. plantarum \\
\hline & CNRZ 764 & 49 & & 100 & & L. plantarum \\
\hline & CST 10952 & ND & & 87 & & L. plantarum \\
\hline & CST 11019 & 20 & & 97 & & L. plantarum \\
\hline & CST 11023 & ND & & 90 & & L. plantarum \\
\hline & DSM 2648 & ND & & 81 & & L. plantarum \\
\hline & NCIMB 6461 & ND & & 80 & & L. plantarum \\
\hline 2 & LP $85-2$ & 18 & 11.4 & 79 & 3 & L. plantarum \\
\hline \multirow[t]{4}{*}{3} & ATCC 10776 & 23 & & 57 & & Lactobacillus sp. \\
\hline & CNRZ $1885^{\mathrm{T}}$ & 14 & & 41 & & Lactobacillus sp. \\
\hline & CNRZ 1887 & 14 & & 43 & & Lactobacillus $\mathrm{sp}$. \\
\hline & $61 \mathrm{D}$ & 17 & & 41 & & Lactobacillus sp. \\
\hline \multirow[t]{3}{*}{5} & ATCC $8008 \mathrm{~B}$ & 0 & & 0 & & Lactobacillus sp. \\
\hline & ATCC $8008 \mathrm{G}$ & 0 & & 0 & & Lactobacillus sp. \\
\hline & NCIMB 3254 & ND & & 65 & 8 & Lactobacillus sp. \\
\hline
\end{tabular}

${ }^{a}$ ND, not determined.

tained with the group 1 strains (levels of relative binding, $>80 \%$ ) (Table 4) and with the one group 2 strain, strain LP 85-2 (level relative binding, $79 \% ; \Delta T_{m}, 3^{\circ} \mathrm{C}$ ) (Table 4 ). When LP 85-2 was hybridized with L. paraplantarum CST $10967^{\mathrm{T}}$, a level of relative binding of less than $26 \%$ was obtained (data not shown). As defined by Wayne et al. (23), two strains belong to the same species when their DNAs have a level of similarity of $\geq 70 \%$ and a maximum $\Delta T_{m}$ of $5^{\circ} \mathrm{C}$. Therefore, we considered the group 1 and 2 strains $L$. plantarum strains. This was not the case with the group 3, 4, and 5 strains (Table 4) because the levels of relative binding between the DNAs of these strains and the DNA of the $L$. plantarum type strain were less than $65 \%$.

\section{DISCUSSION}

Unlike L. plantarum, L. pentosus typically produces acid from glycerol and D-xylose but not from melezitose. This characteristic was found to be misleading in some cases. Strains CNRZ 1538 and CNRZ 1544 fermented glycerol and melezitose but not the pentose D-xylose. They also did not ferment ribose, another pentose fermented by all of the other lactobacilli tested in this study. These strains were atypical in their sugar fermentation phenotype but not at the DNA level. The results of liquid DNA-DNA hybridization with the type strains (Table 4) and Southern-type hybridization with the L. plantarum pyrDFE probe (Table 3) showed that CNRZ 1538 and CNRZ 1544 are L. pentosus strains. These strains may be isogeneic since they had the same sugar fermentation profile
(Table 2), the same origin, and similar plasmid contents. RuizBarba et al. (18) isolated CNRZ 1538 and CNRZ 1544 from Spanish-style fermented green olives (as strains LPC 4 and LPC 16, respectively) and showed that they harbored five plasmids having similar molecular weights. If the genes encoding xylose catabolism are on plasmids, they may be more unstable than chromosome-encoded genes and not appropriate to use as criteria in taxonomic studies. However, at least in L. pentosus MD 353, xylose catabolic genes have been cloned from the chromosome and sequenced (15). Erroneous classifications based on plasmid-encoded phenotypes have occurred; the $L$. casei strains which had lost their lactose plasmid (14) were placed in the subspecies alactosus. However, on the basis of DNA relatedness studies (13), they were placed in the subspecies casei and later renamed L. paracasei by Collins et al. (5). We isolated $L$. pentosus strains which do not ferment the pentoses $\mathrm{D}$-xylose and ribose but ferment arabinose, a pentose catabolized by all of the other $L$. pentosus strains studied (Table 2).

In an effort to develop a simple method to distinguish lactobacilli related to $L$. plantarum, we assessed a method based on Southern-type hybridization between an $L$. plantarum pyrDFE DNA probe and Lactobacillus genomic DNA BglI digests. A total of 68 lactobacilli were classified into five groups on the basis of the sizes of bands obtained (Tables 3 and 4). All $32 L$. plantarum strains tested were members of group 1 and group 2 . Group 2 contained only strain LP 85-2, which may be a representative of a new subspecies of $L$. plantarum and is discussed below. When strain LP 85-2 was hybridized with the 
pyrDFE probe, we detected two $B g l \mathrm{l}$ bands (at 5 and $1.1 \mathrm{~kb}$ ) instead of the three bands (at 7, 4, and $1 \mathrm{~kb}$ ) detected with $L$. plantarum ATCC $14917^{\mathrm{T}}$. We detected no plasmids in strain LP 85-2 (data not shown), although plasmids are frequently found in lactobacilli (13). As determined by SfiI pulsed-field gel electrophoresis macrorestriction (4), the genome size of LP 85-2 was estimated to be $3 \mathrm{Mb}$, which made this genome the smallest of the L. plantarum genomes tested; the genome sizes of strains CCM 1904, CST 11031, CST 11019, and CST 11023 were $3.3,3.8,3.9$, and $3.9 \mathrm{Mb}$, respectively. Strain LP 85-2 produced only two of the five bands detected in the L. plantarum type strain, compared to the three or four bands detected in other L. plantarum strains (a Southern blot of total Eco RI genomic DNA digests was hybridized with an L. plantarum $5 \mathrm{~S}$ ribosomal DNA probe [4]). Of the L. plantarum DNAs tested, LP 85-2 DNA had the lowest level of similarity with $L$. plantarum ATCC $14917^{T}$ DNA (Table 4), so the stability of the heteroduplex $\left(\Delta T_{m}\right)$ was determined. According to Grimont (11), DNAs from members of the same species form heteroduplexes with $\Delta T_{m}$ values less than $5^{\circ} \mathrm{C}$; if the $\Delta T_{m}$ is between 2.5 and $5.5^{\circ} \mathrm{C}$, then the strains belong to different subspecies. We estimated that the $\Delta T_{m}$ of the heteroduplex between ATCC $14917^{\mathrm{T}}$ and LP $85-2$ was $3^{\circ} \mathrm{C}$, suggesting that strain LP 85-2 may be a member of a subspecies of $L$. plantarum. Other strains besides LP 85-2 must be found if $L$. plantarum is going to be split into subspecies.

The group 5 lactobacilli did not hybridize under our Southern-type hybridization conditions and were different from $L$. plantarum, $L$. pentosus, and $L$. paraplantarum. For instance, NCIMB 3254 exhibited a relative binding value of $65 \%$ when it was hybridized with the $L$. plantarum type strain, and the $\Delta T_{m}$ was $8^{\circ} \mathrm{C}$ (Table 4 ), showing that this strain is not an $L$. plantarum strain. When it was hybridized with $L$. paracasei ATCC 334 and L. casei NCIMB $11970^{\mathrm{T}}$, we obtained levels of relative binding of 100 and $16 \%$, respectively (data not shown), demonstrating that NCIMB 3254 is an L. paracasei strain. Strain CST 10966J exhibited less than $4 \%$ relative binding with the DNAs of the type strains of $L$. plantarum, L. pentosus, L. casei, $L$. paracasei, and $L$. rhamnosus (data not shown); therefore, the taxonomic position of this strain remains unknown. Strains ATCC 8008B and ATCC $8008 \mathrm{G}$ did not hybridize with either the L. plantarum type strain or the $L$. pentosus type strain, confirming the conclusion of Dellaglio et al. (9) that strain ATCC 8008 was not an L. plantanum or $L$. pentosus strain. Since no bands were detected with the $L$. plantarum pyrDFE probe, these lactobacilli are not $L$. paraplantarum strains either.

In conclusion, we developed a simple and reliable method to distinguish strains of L. plantarum (groups 1 and 2), L. pentosus (group 4), and L. paraplantarum (group 3). This method may help distinguish additional taxa when it is used with a larger number of lactobacilli.

\section{ACKNOWLEDGMENTS}

We thank F. Gasser, A. Mourey, and E. Armau for kindly sending strains. We thank B. Stefanik and D. Walter for technical assistance.

\section{REFERENCES}

1. Abdi, A. 1992. Contribution à l'étude de la chaîne de biosynthèse de novo des nucléotides pyrimidiques chez Lactobacillus plantarum. Thèse de DoctoratDomaine de Biologie Cellulaire et Moléculaire. Université Louis-Pasteur de Strasbourg, Strasbourg, France.
2. Bouia, A., F. Bringel, L. Frey, A. Belarbi, A. Guyonvarch, B. Kammerer, and J.-C. Hubert. 1990. Cloning and structure of the pyrE gene of Lactobacillus plantarum CCM 1904. FEMS Microbiol. Lett. 69:233-238.

3. Champomier, M.-C., M.-C. Montel, and R. Talon. 1989. Nucleic acid relatedness studies on the genus Carnobacterium and related taxa. J. Gen. Microbiol. 135:1391-1394.

4. Chevallier, B., J.-C. Hubert, and B. Kammerer. 1994. Determination of chromosome size and number of $r m$ loci in Lactobacillus plantanim by pulsed-field gel electrophoresis. FEMS Microbiol. Lett. 120:51-56.

5. Collins, M. D., B. A. Phillips, and P. Zanoni. 1989. Deoxyribonucleic acid homology studies of Lactobacillus casei, Lactobacillus paracasei sp. nov., subsp. paracasei and subsp. tolerans, and Lactobacillus rhamnosus sp. nov., comb. nov. Int. J. Syst. Bacteriol. 39:105-108.

6. Collins, M. D., U. Rodrigues, C. Ash, M. Aguirre, J. A. E. Farrow, A. Martinez-Murcia, B. A. Phillips, A. M. Williams, and S. Wallbanks. 1991. Phylogenetic analysis of the genus Lactobacillus and related lactic acid bacteria as determined by reverse transcriptase sequencing of 16S rRNA. FEMS Microbiol. Lett. 77:5-12.

7. Curk, M.-C., J.-C. Hubert, and F. Bringel. 1996. Lactobacillus paraplantarum sp. nov., a new species related to Lactobacillus plantarum. Int. J. Syst. Bacteriol. 46:595-598

8. Curk, M.-C., F. Peladan, and J.-C. Hubert. 1994. Fourier transform infrared (FTIR) spectroscopy for identifying Lactobacillus species. FEMS Microbiol. Lett. 123:241-248.

9. Dellaglio, F., V. Bottazzi, and M. Vescovo. 1975. Deoxyribonucieic acid homology among Lactobacillus species of the subgenus Streptobacterium Orla-Jensen. Int. J. Syst. Bacteriol. 25:160-172.

10. Fred, E. B., W. H. Peterson, and J. A. Anderson. 1921. The characteristics of certain pentose-destroying bacteria, especially as concerns their action on arabinose and xylose. J. Biol. Chem. 48:385-412.

11. Grimont, P. A. D. 1984. DNA/DNA hybridization in bacterial taxonomy, p. 11-19. In A. Sanna and G. Morace (ed.), New horizons in microbiology. Elsevier Science Publishers B. V., Amsterdam.

12. Grimont, P. A. D., M. Y. Popoff, F. Grimont, C. Coynault, and M. Lemelin. 1980. Reproducibility and correlation study of three deoxyribonucleic acid hybridization procedures. Curr. Microbiol. 4:325-330.

13. Kandler, O., and N. Weiss. 1986. Regular, nonsporing Gram-positive rods, 1208-1234. In P. H. A. Sneath, N. S. Mair, M. E. Sharpe, and J. G. Holt (ed.), Bergey's manual of systematic bacteriology, vol. 2. The Williams and Wilkins Co., Baltimore.

14. Lee, L.-J., J. B. Hansen, E. K. Jagusztyn-Krynicka, and B. M. Chassy. 1982. Cloning and expression of the $\beta$-D-phosphogalactoside galactohydrolase gene of Lactobacillus casei in Escherichia coli K-12. J. Bacteriol. 152:11381146.

15. Lokman, B. C., P. van Santen, J. C. Verdoes, J. Krüse, R. J. Leer, M. Posno, and P. H. Pouwels. 1991. Organization and characterization of three genes involved in D-xylose catabolism in Lactobacillus pentosus. Mol. Gen. Genet. 230: $161-169$.

16. Molin, G., B. Jeppsson, M.-L. Johansson, S. Ahrné, S. Nobaek, M. Ståhl, and S. Bengmark. 1993. Numerical taxonomy of Lactobacillus spp. associated with healthy and diseased mucosa of the human intestines. J. Appl. Bacteriol. 74:314-323.

17. Rose, A. H. (ed.) 1982. Economic microbiology, fermented foods, vol. 7. Academic Press, London.

18. Ruiz-Barba, J. L., J. C. Piard, and R. Jiménez-Díaz. 1991. Plasmid profiles and curing of plasmids in Lactobacillus plantarum strains isolated from green olive fermentations. J. Appl. Bacteriol. 71:417-421.

19. Sharpe, M. E., and G. L. Pettipher. 1983. Food spoilage by lactic-acid bacteria, p. 199-223. In A. H. Rose (ed.), Economic microbiology, food microbiology, vol. 8. Academic Press, London.

20. Southern, E. 1975. Detection of specific sequences among DNA fragments separated by gel electrophoresis. J. Mol. Biol. 98:513-517.

21. Tamura, C., and O. Matsushita. 1992. Melibiose transport system in Lactobacillus plantanum. Microbiol. Immunol. 36:1119-1128.

22. Vanderslice, P., W. C. Copeland, and J. D. Robertus. 1986. Cloning and nucleotide sequence of wild type and a mutant histidine decarboxylase from Lactobacillus 30a. J. Biol. Chem. 261:15186-15191.

23. Wayne, L. G., D. J. Brenner, R. R. Colwell, P. A. D. Grimont, O. Kandler, M. I. Krichevsky, L. H. Moore, W. E. C. Moore, R. G. E. Murray, E. Stackebrandt, M. P. Starr, and H. G. Trüper. 1987. Report of the Ad Hoc Committee on Reconciliation of Approaches to Bacterial Systematics. Int. J. Syst. Bacteriol. 37:463-464.

24. Zanoni, P., J. A. E. Farrow, B. A. Phillips, and M. D. Collins. 1987. Lactobacillus pentosus (Fred, Peterson, and Anderson) sp. nov., nom. rev. Int. J. Syst. Bacteriol. 37:339-341. 